\title{
Determinants of Price Rigidity and Flexibility: Some Survey Evidence for the Pakistan.
}

\author{
NADEEM IQBAL \\ Assistant Professor at the Department of Economics University of Peshawar. \\ Email: nadeemiqbal@uop.edu.pk
}

AMJAD AMIN

Assistant Professor at the Department of Economics University of Peshawar. Email: amjadamin@uop.edu.pk

DANISH WADOOD ALAM

Lecturer at the Department of Economics University of Peshawar.

Email: danish_alam@uop.edu.pk

\begin{abstract}
The objective of the study is to estimate the determinants of price stickiness or flexibility. Data is collected through structured questionnaire from 342 firms, which are selected through stratified random sampling technique from the Industrial Estate of Khyber Pakhtunkhwa. To estimate the determinants of price flexibility/rigidity, models are estimated through ordinary least squares technique and binary logistic technique. The most important factors for price stickiness are implicit/explicit price contracts and minimum price volatility. Imperfect competitive market structure, number of regular customers, backward-looking behavior, and credibility of central bank and size of the firm are important determinants of price rigidity. While economic literacy and information set regarding expected inflation make the prices flexible. Study recommend that monetary policy of Pakistan should use other transmission channels of money supply instead of traditional channel, because it is found that the degree of price rigidity is low in Pakistan.
\end{abstract}

Keywords: Price Rigidity, Price Flexibility, Price Contract, Frequency of Price Change.

\section{Introduction}

The price setting behaviour have a significant implication both in microeconomics and macroeconomics. If price are flexible then the economy will recover quickly from the shock, and if there are nominal rigidities, then adjustment process will be slow. So, policy effectiveness depends on price adjustment process. New Keynesian economists, after incorporating the concept of microfoundation and rational expectation in the macroeconomic model of price rigidity, prove that policy will have real effects no matter it is anticipated or unanticipated (Fischer, 1977; Taylor, 1980; \& Calvo, 1983).

The price-setting behaviour of firms estimated by Taylor (1980), i.e. using fixed duration contracts and by Calvo (1983), i.e. using random-duration contracts has important implication in the economy for the degree of price flexibility or rigidity, but it's difficult to differentiate between the two types of contracts using macroeconomic data. Furthermore, the timing, frequency and magnitude of price change cannot be appropriately determined through analyzing only macroeconomic data. In the last three decades, these Keynesian models of price stickiness gain popularity because of the empirical analysis on price setting behaviour of firms at the micro level. Blinder (1991) is the pioneer, who study price setting by using survey based data and open a new window for research to work on nominal rigidities by using micro data. 
In microeconomics, these nominal rigidities in term of price divide the markets into two types; perfectly competitive firms and imperfectly competitive firms. The price setting behaviour of firms facing imperfect competition lead to inefficiency because they are already producing below the optimal level that is consistent with perfect competition (Iqbal \& Amin, 2019; and Da Silva, Pretrassi \& Santos, 2016). Economic literature identifies various reasons of price stickiness, i.e. menu cost, implicit/explicit contracts and customer relations (Singh \& Ru, 2019; and Pasten, Schoenle \& Weber, 2020).

The objective of the study is to analyse the determinants of price rigidity using primary data, collected from the firms located in the industrial estates of Khyber Pakhtunkwa, furthermore to estimate that prices are sticky or flexible. The rest of the paper is organized as: in section 2 theoretical framework is discussed, in section 3 the econometric methodology is explained, section 4 explain the data collection procedure, section 5 consists of results and section 6 include conclusion.

\section{General Staggered Price Setting Model}

As the behaviour of price setting behaviour is heterogeneous across firms and concerning time. So, it is necessary to give a more general form of price setting model, because simple staggered price setting model is based on uniform contract length, which is unable to explain the behaviour of different contract length. This model assumed that instead of changing the price in each period, it is assumed that there are different types of contract with different length, i.e. $\mathrm{N}_{1}, \mathrm{~N}_{2}, \mathrm{~N}_{3}, \ldots$, represent different types of price contracts. Some price will be set for a longer period and other for a smaller period, which shows heterogeneity in price setting behaviour. The following equation gives the price setting equation in more general form.

$$
p_{t}=\pi_{0} z_{t}+\pi_{1} z_{t+1}+\pi_{2} z_{t+2}+\pi_{3} z_{t+3}+\ldots+\pi_{n} z_{t+n}
$$

Where $\pi_{i}(\mathrm{i}=1,2,3 \ldots \mathrm{n})$ is the weight given to different contracts set by different firms, and its values are different for a different contract, while in the simple model, it is homogenous across firms. Taylor (1980) used equation (1) in different ways for different types of contract and did not restrict the parameter and found a general frequency distribution for different contracts, some firms set price each quarter, some for two or three quarter and some for one year. Calvo (1983) modified generalize form of price setting, i.e. equation (1) into a simple and more useful form, according to Calvo (1983) model weight $\left(\pi_{i}\right)$ of different price contract $\left(z_{i}\right)$ follow a simple geometric series. Calvo (1983) model gave the behaviour of weightage $\left(\pi_{i}\right)$ follow exponential, i.e. $\pi_{i}=\beta^{i}$, where " $\mathrm{i}$ " $<1$. According to this model, the behavior of price is stochastic and independent of each other. According to the model the staggered price setting model follow random behaviour of contract length because the price contract can end any time i.e. random shown by exponential behaviour of weightage $\left(\pi_{i}\right)$.

\section{Econometric Model and Technique}

On the basis of past empirical studies, staggered price setting model and objectives of the study, the following model is constructed.

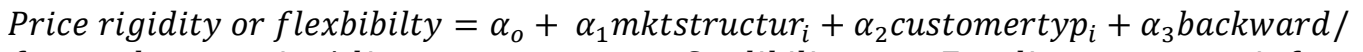
forward $_{i}+\alpha_{4}$ priceAdjutmentproces $_{i}+\alpha_{5}$ Credibility $_{i}+\alpha_{6}$ Econliteracy $_{i}++\alpha_{7}$ informatset $_{i}+$ $\alpha_{8}$ firmsiz $_{i}+e_{i}$

Equation (2) consists of the determinants of price setting. Price setting is the dependent variable. The price setting variable is measured through price rigidity. Price rigidity is measured through two proxies: First through frequency of price change i.e. on average the number of times the firm changes the price of its main product in one year. To measure it the firm is asked, that on average how many times you change the price of your product in one year. The number of times price changes represent the degree of rigidity or flexibility. As the number increases from $0,1,2 \ldots$ it means the degree of rigidity decreases and flexibility 
increase. Second, price rigidity is measured through implicit and explicit price contract, i.e. firms are asked whether they engage in price contract for periods longer than one year. The contract is also a source of price rigidity over a certain period, therefore it measures the degree of price rigidity. The response is coded as, Yes $=1$ and No $=0$ for construction of dummy variable; " 1 " means price rigidity and " 0 " means price flexibility.

To estimate the determinants of price flexibility/rigidity, each proxy of price setting behaviour is regressed on a set of explanatory variables as shown in Equation (2). The selection of model depend on the nature of dependent variables and diagnostic tests.

Equation (2) is estimated through ordinary least squares technique in case of frequency of price change as dependent variable, as it is in continuous form and the results of other pre-requisites of using ordinary least square technique is tested. While binary logistic technique is used in case of price contract, as it is in binary form. The independent variables are: market structure, type of customers, backward-looking and forwardlooking, price adjustment process, credibility of central bank, economic literacy, information set about expected inflation and firm size. The construction of independent variables is discussed in detail in section 5 .

\section{Data Collection}

In Khyber Pakhtunkhwa, there are 14 industrial estates, in which 06 are large and 08 are small industrial estates. Four large industrial estates i.e. Hayatabad, Gadoon Amazi, Hattar and Nowshera industrial estate are selected for initial population. Dera Ismail khan and Exporting Processing Risalpur are large industrial estates but not selected, because it's still under construction and most of the units are closed and nonoperational. Following Neagu \& Braun-Erdei, (2006) methodology, the filtered population is 860 firms in the four industrial estates, out of this 342 firms are selected through stratified random sampling technique at 95\% confidence error and 5\% margin error. Firms who have less than 10 number of workers are not included in the population. Firms are who not involved in production in 2017 are not included in the initial population and those who are registered after 2017 are excluded from initial population (Neagu \& BraunErdei, 2006).

\section{Results}

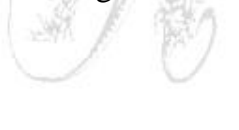

\section{Determinants of Price Stickiness}

To test the assumptions of macroeconomic theories, on the which macroeconomic models of price stickiness are based and to analyze the importance of various factors in keeping prices sticky, the firms are asked different questions, which are based on the various possible explanation of previous literature and economic theories. Certain fundamental theories which explain the reasons of price stickiness are: explicit contracts, Menu cost theories, information and decision cost, coordination failure, implicit contract theory, minimum price volatility and less uncertainty; and firm's signal extraction problem.

Based on above theories, the firms are asked to rank the importance of the factors given in table 1 from unimportant to very important. If mean value is greater than 2 , then the factor is important determinant of price stickiness, otherwise no. According to the table all factors are important factors for price stickiness because the mean value of all factors is almost equal or greater than 2. But the most important factors are found, in the order of preference, the implicit contract, explicit contracts and then minimum price volatility; because the mean of values of the importance of these factors in price stickiness is almost 3 as shown in table 1 . 
Table: 1 Determinants of Price Stickiness

\begin{tabular}{|c|c|c|c|c|c|}
\hline Variables & 1 & 2 & 3 & 4 & Mean \\
\hline Implicit contract theory & 40 & 54 & 124 & 124 & $2.9^{*}$ \\
\hline Explicit contracts theory & 72 & 84 & 68 & 118 & $2.6^{*}$ \\
\hline Coordination failure & 90 & 56 & 90 & 106 & $2.6^{*}$ \\
\hline Firm's signal extraction problem & 118 & 68 & 80 & 76 & $2.3^{*}$ \\
\hline Menu cost theories & 138 & 94 & 52 & 58 & $2 *$ \\
\hline Minimum price volatility and less uncertainty & 140 & 118 & 44 & 40 & $1.9^{*}$ \\
\hline Information and decision cost & 142 & 106 & 66 & 28 & $1.9^{*}$ \\
\hline \multicolumn{6}{|c|}{$\begin{array}{l}1=\text { Unimportant; } 2=\text { less important; } 3=\text { Important and } 4=\text { Very Important. *means } \\
1 \% \text { significance level. Mean show the average of the importance of shocks in } \\
\text { price change. }\end{array}$} \\
\hline
\end{tabular}

\section{Determinants of Price Rigidity or Flexibility}

This section analyses the determinants of price rigidity or flexibility. Two variables are taken to measure price rigidity or flexibility, which is the dependent variable, i.e. the frequency of price change and price contract.

\section{Price-setting (Frequency of Price change)}

According to results in table 2, if firms having imperfect competitive nature instead of perfect competitive then the frequency of change will decrease. It means in case of imperfectly competitive market structure, the frequency of firms to change price is less than the firms who operate in a perfectly competitive market structure, because they have the monopoly power and can set the price according to internal policies of the firm. While in case of perfectly competitive market structure, firms depend on the market conditions (Nakamura et al. 2011). Furthermore, perfectly competitive firms mostly follow state-dependent pricing policy and specific event, e.g. demand shocks can affect the price of their products, that's why prices are flexible in case of competitive firms (Kaplan and Menzio, 2015). Singh \& Ru, (2019) found that market clearing policy prevails and the prices are flexible as the number of competitors' increases.

It is also found that, if firm have occasional customer instead of regular customers then the frequency of price change will be high. It shows that if firms have occasional customers, then there is more chance that prices of products will be flexible. It can be concluded that if the number of the regular customers is more than the occasional customers, then the behaviour of prices will be rigid (Esteves, 2010), because the firm will take care of regular customers. According to Iqbal \& Amin, (2019), the chances of the firms to change price is low in the case of regular customers, because of the long-term bond between the firm and regular customers. Furthermore, to make the regular customers more loyal with the firms and to maintain the market share, the chances of firms to change price due to shocks in the economy is low in case of the regular customer then occasional customers (Baye and Morgan 2009). It shows that the result is also in line with the previous literature. It means the type of customers affect the frequency of price, i.e. price-setting. It can be inferred that firms do care about the type of customers, i.e. regular or occasional, which supported the economic theories, i.e. implicit price contract theory (Pasten, Schoenle \& Weber, 2020).

Firms use three types of information to determine the price of their products, i.e. past information, current information and forecast about the future. Price information is a critical determinant of price rigidity and flexibility. According to table 2, if firm used current information instead of past information, then the frequency of price change will be high. So, it can be inferred that if firm used past information in pricing decisions then the prices will be rigid, while in case of current information, the price will be flexible. Because as the information set increases, the firm can predict the current economic situation more accurately, due to which the firm will be able to set an optimal price and will revise more frequently. According to Iqbal \& Amin, (2019 collecting information to review price is costly, and it may be rational to 
follow the announcement of policy maker and actively update the information set. It means backwardlooking behaviour (i.e. past information) and forward-looking behaviour (i.e. current information and forecast about future) have important implication for frequency of price change (Andrade and Le Bihan, 2013).

According to results in table 2, firms who consider central bank credible, then the probability of these firms to change price will be lower than other firms, who consider central bank non-credible and will lead to price rigidity. This result is consistent with the empirical evidence and economic theories. Monetary policy will be strengthened and useful, if central banks are considered credible by the people, because then the private sector will trust on policies of central bank and will set price of its product accordingly and the frequency of price change will be low (Borraz, Licandro, \& Sola, 2020).

According to results in table 2, if firms have economic literacy, then the frequency of price change will be high. It means if firm's owners learn about current economic conditions and economic policies then the frequency of price change will increase. According to economic theories, economic literacy can have positive or negative impact on frequency of price change, because it depends that either it is related to demand shocks or supply shocks. In Pakistan, industrial estates mostly face supply shocks, that's why if firms have economic literacy, then the probability of price change will be high. Because as literacy about current economic conditions increases, the firm can more accurately predict economic situation and the firm will change the price more frequently and the price will be more flexible (Bruine de Bruin et al., 2010).

According to results in table 2 information set regarding expected inflation has a positive on the frequency of price change. It means as information set regarding expected inflation increases, the frequency of price change will be high, and the prices will be flexible. Wolman, (2000) and Wang \& Werning, (2020) found that set of information about expected inflation make the price more flexible than unexpected inflation.

Table 2 Price-setting Behavior (Frequency of Price Change)

\begin{tabular}{|c|c|c|c|c|}
\hline Variables & Categories & B & SE & Sig \\
\hline Constant & & 2 & 0.6 & 0.0 \\
\hline \multirow{4}{*}{ Market Structure } & Competition & & & \\
\hline & Monopolistic Competition & -.04 & 0.3 & 0.8 \\
\hline & Oligopoly & -0.5 & 0.2 & 0.0 \\
\hline & Monopoly & -0.3 & 0.2 & 0.0 \\
\hline \multirow{3}{*}{ Customer Type } & Regular Customer & & & \\
\hline & Both & 1.0 & 0.3 & 0.0 \\
\hline & Occasional Customer & 0.8 & 0.3 & 0.0 \\
\hline \multirow{3}{*}{$\begin{array}{l}\text { Backward-looking and } \\
\text { Forward-looking Behaviour }\end{array}$} & Past Information & & & \\
\hline & Current Information & 0.5 & 0.2 & 0.0 \\
\hline & Forecast about future & 0.1 & 0.2 & 0.5 \\
\hline \multirow{2}{*}{ Credibility } & No & & & \\
\hline & Yes & -0.6 & 0.2 & 0.0 \\
\hline \multirow{2}{*}{ Economic Literacy } & No & & & \\
\hline & Yes & -0.4 & 0.1 & 0.0 \\
\hline Information Set* & & 1.1 & 0.5 & 0.0 \\
\hline Firm size & & -0.6 & 0.1 & 0.0 \\
\hline
\end{tabular}

According to results in table 2, if the size of the firm increases then the occurrence of price change will decrease. So, it can be inferred that the size of the firm, i.e. small, medium and large size does influence the frequency of price change per year and as the size increases, the price will become more rigid. According 
to Jonker, Folkertsma and Blijenberg, (2004), price-setting with respect firm size shows that prices are more flexible in small firms than large firms.

\section{Price-setting (Price Contracts)}

In this section, price-setting is proxied by price contracts, i.e. do the firms engage in price contracts for a period longer than one year? Which measured the intensity of price rigidity and it is taken as a dependent variable in table 3 .

According to results in table 3 , if firms having imperfect competitive market structure instead of perfect competitive than the chance of being involved in contract is higher than the chance of being not involved in contract. It means the probability of firms to engage in price contract increases as the number of competitors' decreases. The relationship between market structure and price flexibility has prominently figured out in the previous literature, in monopoly the prices are stickier then competition.

According to results in table 3, if firm have occasional customers instead of regular customers then the chances of firms to be engage in price contract is low. It means in case of regular customers the prices will be more rigid than in the case of occasional customers. According to the Esteves (2010), the price will be rigid due to shocks in the economy, if the ratio of regular customers is greater than occasional customers. The bargaining power of regular customers is more than occasional customers, because of implicit contracts, that's why the price becomes more rigid. To make the regular customers more loyal with the firms and to maintain the market share, the chances of firms to keep prices stable due to shocks in the economy is high in case of the regular customers then occasional customers (Baye and Morgan 2009).

According to results in table 3 , if firm pricing decisions are based on current information instead of past information, then the chance of being involved in the contract is less than the chance of being not engaged in contract. It means firms who are backward-looking have a high probability of being involved in price contracts then forward-looking firms, its means backward-looking firms are the source of price rigidity and channel of policy effectiveness, and it is in line with the previous literature.

Adam and Padula (2011) estimate that the weightage of backward-looking is more than forward-looking in the components of inflation. The role of backward-ward looking is more because the firm does not compute prices but set according to a rule of thumb (Iqbal \& Amin, 2019). Reis (2009) show that effectiveness of monetary policy depends on the degree of backward-looking behaviour and forward-looking behaviour in price-setting because backward-forward looking behaviour determines the speed of price adjustments.

According to results in table 3 , the chances of firm to be engaged in price contracts is independent of price adjustment process; after calculation if the firm finds that it should change the price of its product by less than or equal to $5 \%$ i.e. in one shot, gradually or according to situation. Generally, its fine: firms which involve in contract will change price in one shot, but it is also equally possible that whenever price change is required, they are unable to change. This result is in line with empirical evidence and previous literature because those firm who are engaged in price contract, price adjustment process is meaningless, because the behaviour of firms depend on the type of contract (Malik et al, 2008).

According to results in table 3 if a firm considers central bank more credible instead of non-credible, then the chance of firms of being involved in price contract is higher than the chance of being not involved in price contract for periods longer than one year. The result is consistent and in line with the literature and economic theories. The credibility of the central bank neither lead to high inflation nor deflation, but it keeps the price stable. So, it can be concluded that the credibility of central is a source of rigidity, i.e. price contract (Kong, 2020) 
According to results in table 3 as the economic literacy of firm increases, then the chance of the firm being involved in contract is higher than the chance of being not involved in contract. The set of information of firm about the economic situation and policies is the critical determinant of price contract, i.e. price rigidity (Iqbal \& Amin, 2019) because then the firm can forecast the future state of the economy more accurately and precisely.

According to results in table 3, if information set regarding expected inflation increases then the chances of being involved in price contract decreases because the odd value is less than one, which implies that if firm information about expected inflation increase then the prices will be less rigid. It is in line with the previous literature. According to Wolman (2000) and L'Huillier, (2020) as the set of information about expected inflation due to economic shocks, the firms will avoid price contracts for longer than one year.

According to table 3, the chance of the firms to be involved in the contract is independent of the size of firms. It means as the size of firms increases (decreases) does not affect the chances of firms to engage in price contract. Literature gives a mixed result about the impact of firm size. According to previous studies, prices are rigid in case of small firms, because they have high chance to be involved in price contract, while in case of large firm the prices are flexible, because the probability of large firms to engage in price contract is low. The results seem plausible, but it may because of menu cost and large firms can change menu easily because of economies of scale (Jonker, Folkertsma and Blijenberg, 2004).

\begin{tabular}{|c|c|c|c|c|c|}
\hline Variables & Categories & B & S.E. & Sig. & $\operatorname{Exp}(B)$ \\
\hline Constant & & 0.5 & 1.0 & 0.5 & 1.7 \\
\hline \multirow[t]{4}{*}{ Market Structure } & Competition & & & 0.0 & \\
\hline & Monopolistic Competition & -0.3 & 0.5 & 0.4 & 0.6 \\
\hline & Oligopoly & .03 & 0.3 & 0.9 & 1 \\
\hline & Monopoly & 0.6 & 0.3 & 0.0 & 1.5 \\
\hline \multirow[t]{3}{*}{ Customer Type } & Occasional Regular Customer & & & 0.3 & \\
\hline & Both & -0.5 & 0.6 & 0.3 & 0.5 \\
\hline & Occasional Customer & -1.5 & 0.5 & 0.0 & 0.8 \\
\hline \multirow{3}{*}{$\begin{array}{l}\text { Backward-looking and } \\
\text { Forward-looking Behavior }\end{array}$} & Past Information & & & 0.0 & \\
\hline & Current Information & -2 & 0.4 & 0.0 & 0.1 \\
\hline & Forecast about future & -0.2 & 0.4 & 0.4 & 0.7 \\
\hline \multirow[t]{3}{*}{ Price Adjustment Process } & In one shot & & & 0.3 & \\
\hline & Gradually & -.03 & 0.4 & 0.9 & 0.9 \\
\hline & Depend on situation & 0.4 & 0.3 & 0.1 & 1.5 \\
\hline \multirow[t]{2}{*}{ Credibility } & No & & & & \\
\hline & Yes & 1.1 & 0.3 & 0.0 & 3.1 \\
\hline \multirow[t]{2}{*}{ Economic Literacy } & No & & & & \\
\hline & Yes & 1.5 & 0.8 & 0.0 & 4.5 \\
\hline Information Set* & & -1.5 & 0.8 & 0.0 & 0.2 \\
\hline Firm size & & .01 & 0.2 & 0.9 & 1.0 \\
\hline
\end{tabular}

\section{Conclusion}

According to results, the most important factors for price stickiness are the implicit/explicit price contracts, and minimum price volatility. Imperfect competitive market structure of firms, number of regular customers, backward-looking firms, credibility of central bank and the size of the firm are the important determinants of price rigidity, because these determinants increase the chances of the firms to be engage in 
price contract and decrease the frequency of price chance. While economic literacy and information set regarding expected inflation make the prices flexible. Because if firm's owners learn about current economic conditions and economic policies and as information set regarding expected inflation increases, then the frequency of price change will be high and the chances of being involved in price contract decreases, and the prices will be flexible. The paper recommend that as it is found that degree of price rigidity is low in Pakistan, so the traditional channel of monetary policy will be ineffective or weak. Because the traditional channel through which effects of monetary policy transmit into the economic activity and inflation depends on price rigidity. Therefore the central bank should focus on other channel of transmission mechanism of money.

\section{References}

Adam, K., \& Padula, M. (2011). Inflation dynamics and subjective expectations in the United States. Economic Inquiry, 49(1), 13-25.

Andrade, P., \& Le Bihan, H. (2013). Inattentive professional forecasters. Journal of Monetary Economics, 60(8), 967-982.

Baye, M. R., \& Morgan, J. (2009). Brand and price advertising in online markets. Management Science, 55(7), 1139-1151.

Blinder, A. S. (1991). Why are prices sticky? Preliminary results from an interview study (No. w3646). National Bureau of Economic Research.

Borraz, F., Licandro, G., \& Sola, D. (2020). Wage and price setting: new evidence from Uruguayan firms. Journal of Applied Economics, 23(1), 560-582.

Bruine de Bruin, W., Potter, S., Rich, R. W., Topa, G., \& Van Der Klaauw, W. (2010). Improving survey measures of household inflation expectations. Current Issues in Economics and Finance, 16(7).

Calvo, G. (1983). Staggered Prices in a Utility-Maximizing Framework. Journal of Monetary Economics, 12, 383-398.

Da Silva Correa, A., Petrassi, M. B. S., \& Santos, R. (2016). Price-Setting Behavior in Brazil: survey evidence (No. 422).

Esteves, R. B. (2010). Pricing with customer recognition. International Journal of Industrial Organization, 28(6), 669-681.

Fischer, S. (1977). Long-term contracts, rational expectations, and the optimal money supply rule. Journal of political economy, 85(1), 191-205.

Iqbal, N., \& Amin, A. (2019). Some Preliminary Evidence of Price Setting Behaviour from the Industrial Estates of Khyber Pakhtunkhwa. Review of Economics and Development Studies, 5(4), 791-798.

Jonker, N., Folkertsma, C., \& Blijenberg, H. (2004). An Empirical Analysis of Price Setting Behavior in the Netherlands in the Period 1998-2003 Using Micro Data.

Kaplan, G., \& Menzio, G. (2015). The morphology of price dispersion. International Economic Review, 56(4), 1165-1206.

Kong, T. Y. (2020). The Advance of Marketization in North Korea: Between political rigidity and economic flexibility. Modern Asian Studies, 54(3), 830-867.

L'Huillier, J. P. (2020). Consumer Imperfect Information and Endogenous Price Rigidity. American Economic Journal: Macroeconomics, 12(2), 94-123.

Malik, W. S., Satti, A. U. H., \& Saghir, G. (2008). Price setting behaviour of Pakistani firms: Evidence from four industrial cities of Punjab. The Pakistan Development Review, 247-266.

Nakamura, A. O., Nakamura, E., \& Nakamura, L. I. (2011). Price dynamics, retail chains and inflation measurement. Journal of Econometrics, 161(1), 47-55.

Neagu, F., \& Braun-Erdei, H. (2006). Survey Evidence on Price Setting Patterns of Romanian Firms. Romania: Public Policy Centre Research Associate and National Bank of Romania.

Pasten, E., Schoenle, R., \& Weber, M. (2020). Price rigidity and the granular origins of aggregate fluctuations. Chicago Booth Research Paper, (17-25), 2018-54.

Reis, R. (2009). A sticky-information general-equilibrium model for policy analysis (No. w14732). National Bureau of Economic Research. 
Singh, S., \& Ru, C. G. (2019). Price rigidity, market competition, and product differentiation. Economic research-Ekonomska istraživanja, 32(1), 2941-2958.

Taylor, J. (1980). Aggregate Dynamics and Staggered Contracts. Journal of Political Economy, 1-23.

Wang, O., \& Werning, I. (2020). Dynamic Oligopoly and Price Stickiness. NBER Working Paper, (w27536).

Wolman, A. L. (2000). The frequency and costs of individual price adjustment. FRB Richmond Economic Quarterly, 86(4), 1-22. 